\title{
Inhibition of Neurite Growth by the NG2 Chondroitin Sulfate Proteoglycan
}

\author{
Chang-Lin Dou and Joel M. Levine \\ Department of Neurobiology and Behavior, State University of New York at Stony Brook, Stony Brook, New York 11794
}

\begin{abstract}
The chondroitin sulfate proteoglycans (CSPGs) have been implicated as both positive and negative modulators of axonal growth; however, the functional properties of only a few specific CSPGs have been investigated. Here we demonstrate that NG2, an integral membrane CSPG expressed on the surfaces of glial progenitor cells, inhibits neurite growth from neonatal rat cerebellar granule neurons when presented to the cells as a component of the substrate. Growth inhibition occurred when NG2 was mixed with either laminin or L1, two potent promoters of axonal extension. Moreover, when given a choice between surfaces coated with NG2 and laminin or L1, the axons of the cerebellar neurons extended preferentially on laminin or L1 and avoided areas of the substrate containing NG2. The NG2 proteoglycan inhibited neurite growth after digestion with chondroitinase $A B C$, demonstrating that the inhibitory activity is a property of the core protein and not the covalently attached chondroitin sulfate glycosaminoglycan chains. NG2 also inhibited neurite growth from embryonic rat dorsal root ganglia neurons on substrates containing laminin. However, when the sensory neurons were plated onto surfaces containing the L1 glycoprotein and NG2, neurite growth was not inhibited. These results demonstrate that the NG2 proteoglycan provides an unfavorable substrate for axonal growth. Cells that express this proteoglycan in vivo may participate in axonal guidance by defining areas of the developing CNS that are nonpermissive for axonal extension from specific classes of developing neurons.
\end{abstract}

[Key words: chondroitin sulfate proteoglycan, chondroitin sulfate glycosaminoglycan, cell adhesion molecule, laminin, [1, axonal growth]

The proper functioning of the nervous system depends upon the precise and highly stereotyped patterns of neuronal connections that form during development. How growing axons find their appropriate targets remains an essential question in developmental neurobiology. Much attention has been paid to molecules that promote neuronal cell adhesion and neurite outgrowth (for review, see Rutishauser and Jessell, 1988). Cell adhesion molecules such as $\mathrm{N}$-cadherin, $\mathrm{Ll}$, and N-CAM are abundant in developing tissues (Rutishauser and Jessell, 1988) as are the

\footnotetext{
Received Mar. 31, 1994; revised May 26, 1994; accepted June 8, 1994

We thank Ds. Lemmon, Halegoua and Bicknese for their comments on the manuscript. This work was supported by Grant NS21198 from the NIH.

Correspondence should be addressed to Joel M. Levine, Department of Neurobiology and Behavior, SUNY at Stony Brook, Stony Brook, NY 11794.

Copyright (C) 1994 Society for Neuroscience $0270-6474 / 94 / 147616-13 \$ 05.00 / 0$
}

extracellular matrix (ECM) associated molecules, fibronectin and laminin (Sanes, 1989). Although these molecules are capable of supporting neurite outgrowth, most neurons show little ability to discriminate among $\mathrm{L} 1$, laminin, and $\mathrm{N}$-cadherin in vitro (Lemmon et al., 1992).

Recent work from a number of laboratories has identified molecules that can cause growth cone collapse and inhibit neurite extension in vitro. These molecules may provide negative cues or signals important in the formation of axonal connections (for review, see Patterson, 1988; Goodman and Shatz, 1993). For example, Luo and colleagues have identified a $100 \mathrm{kDa}$ membrane glycoprotein, termed collapsin, that induces growth cone collapse of chick dorsal root ganglia (DRG) neurons (Luo et al., 1993). Two glycoproteins of $48 \mathrm{kDa}$ and $55 \mathrm{kDa}$, isolated from embryonic chick somites, also induce the collapse of chick sensory neuron growth cones (Davies et al., 1990). Lastly, Caroni and Schwab (1988a,b) identified two membrane glycoproteins of 250 and $35 \mathrm{kDa}$ from rat CNS myelin that inhibit the growth of rat sensory neurons. With the exception of the myelin associated proteins, which are expressed by oligodendrocytes, most of these putative growth inhibitory molecules have not been associated with specific cell types within the developing nervous system.

One class of macromolecules capable of providing both positive and negative influences over axonal growth are the proteoglycans. These complex molecules consist of a polypeptide chain with covalently attached glycosaminoglycan (GAG) polymers. When complexed to ECM molecules such as laminin, some proteoglycans increase neuronal cell adhesion and axonal elongation (Lander et al., 1985a; Riopelle and Dow, 1990). However, other proteoglycans are nonpermissive for cell attachment and neurite growth (Cole and McCabe, 1991; Oohira et al., 1991; Grumet et al., 1993). Given the molecular diversity of proteoglycans (Herndon and Lander, 1990) and the cellular specificity of their distribution (Levine and Card, 1987; Zaremba et al., 1989; Maeda et al., 1992), the growth-promoting or inhibitory properties of proteoglycans may best be studied by analyzing the effects of individual species of proteoglycans on defined populations of neurons.

One well-characterized CSPG of the CNS is the NG2 proteoglycan. This molecule, which is found on the surfaces of glial progenitor cells in developing and adult tissues (Stalicup et al., 1983; Levine and Card, 1987; Levine et al., 1993), consists of a single core polypeptide of approximately $300,000 \mathrm{Da}$ and two or three chondroitin sulfate chains (Nishiyama et al., 1991). Since glial cells and their precursors may participate in the guidance of growing axons to their targets, we have analyzed the growth modulating properties of the NG2 proteoglycan. Here, we show that developing cerebellar granule neurons extend neu- 
rites poorly on substrates composed of the NG2 proteoglycan and either laminin or L1. This growth inhibitory activity is a property of the NG2 core protein and not the chondroitin sulfate (CS) GAG chains. These data suggest that the developing glial cells that express the NG2 proteoglycan can play a role in axonal targeting by defining regions of the CNS that are nonpermissive for axonal extension.

\section{Materials and Methods}

Reagents. Monoclonal antibody D31.10 against the NG2 proteoglycan core protein and polyclonal rabbit anti-NG2 antibodies were described previously (Stallcup et al., 1983; Levine and Stallcup, 1987). Monoclonal antibody $74-5 \mathrm{H} 7$ against $\mathrm{Ll}$ was generously provided by $\mathrm{Dr}$. V. Lemmon (Lemmon et al., 1989). Poly-L-lysine (PLL), phenylmethylsulfonyl fluoride (PMSF), $N$-ethyl maleimide (NEM), glucose oxidase, lactoperoxidase, chondroitin disaccharide 4-sulfate, chondroitin disaccharide 6-sulfate, normal rabbit serum, and rabbit anti-mouse IgG antiserum were purchased from Sigma. Pansorbin cells and chondroitin sulfate A were purchased from Calbiochem (San Diego, CA). Proteasefree chondroitinase $\mathrm{ABC}$ and quick spin protein columns were obtained from Boehringer Mannheim (Indianapolis, IN). Keratanase was from Seikagaku America Inc. (Rockville, MD). Laminin and basic fibroblast growth factor (bFGF) were from Upstate Biotechnology Inc. (Lake Placid, NY). Lithium 3,5-diiodosalicylate (LIS) was obtained from Eastman Kodak Company (Rochester, NY). ${ }^{125}$ I-iodine was purchased from ICN (Irvine, CA). Protein assay kit was from Bio-Rad (Richmond, CA). Nitrocellulose (type BA85) was purchased from Schleicher and Schuell (Keene, NH); 48-well tissue culture plates were from Costar (Cambridge, MA). Sprague-Dawley rats were maintained and bred in the university animal facility.

Immunoaffinity purification of $N G 2$ and $L 1$. The NG2 proteoglycan was immunoaffinity purified from B49 cells, a NG2-rich rat neuroglial line (Schubert et al., 1974), using a solid phase immunoabsorbent technique (MacSween and Eastwood, 1978). Briefly, the B49 cells were lysed in $1 \%$ Nonidot P40 (NP40), $50 \mathrm{~mm}$ Tris, $\mathrm{pH} 8.0,0.15 \mathrm{~m} \mathrm{NaCl}$ containing 2 mM PMSF. The nuclei were pelleted in a microcentrifuge and discarded. The lysate was cleared by incubation with Pansorbin to which normal rabbit serum had been adsorbed. The cleared lysate was incubated for $1 \mathrm{hr}$ at $4^{\circ} \mathrm{C}$ with Pansorbin that had been preloaded with D31.10 and rabbit anti-mouse IgG and then fixed in $0.5 \%$ paraformaldehyde. Following three washes, the NG2 proteoglycan was eluted from the immunoabsorbent in $0.1 \mathrm{M}$ LIS and the LIS was removed with a quick spin protein column that had been equilibrated in PBS plus $0.05 \%$ sodium azide. The NG2 preparation was then incubated with rabbit anti-mouse IgG-coated Pansorbin to remove any contaminating mouse immunoglobulins that may have leached off the first immunoabsorbent. In some cases, the B49 cells were surface labeled with ${ }^{125} \mathrm{I}-$ iodine by the glucose oxidase-lactoperoxidase method (Hubbard and Cohn, 1972) and NG2 was purificd as described above. Protcin concentrations were determined by the Bradford assay (Bradford, 1976) with bovine serum albumin as a standard. Figure $1 A$ shows the intact and chondroitinase $\mathrm{ABC}$-digested NG2 subjected to SDS-PAGE and visualized by Coomassie blue staining. The NG2 appears as a mixture of a broad high-molecular-weight smear and a single polypeptide band of approximately $300 \mathrm{kDa}$ (lane 2). Digestion with chondroitinase $\mathrm{ABC}$, which removes chondroitin sulfate glycosaminoglycans from CSPGs, converted most the smear into $300 \mathrm{kDa}$ component (lane 3 ).

The $\mathrm{L} 1$ glycoprotein was purified from postnatal day 6 rat brain membranes using monoclonal antibody $74-5 \mathrm{H} 7$ and the same immunoabsorbent technique. Brain tissue was homogenized in $0.3 \mathrm{~m}$ sucrose, 4 mM HEPES, pH 7.4 in the presence of protease inhibitors and centrifuged at $12,000 \times g$ for $30 \mathrm{~min}$. The supernatant was then centrifuged at $100,000 \times g$ for $45 \mathrm{~min}$ to pellet the membrancs. The membranes were extracted in $1 \%$ deoxycholate, $50 \mathrm{~mm}$ Tris, $\mathrm{pH} 8.0,0.15 \mathrm{M} \mathrm{NaCl}$ plus $2 \mathrm{mM}$ PMSF and $2 \mathrm{mM}$ NEM. The membrane extract was then cleared with normal rabbit serum-coated Pansorbin and immunoprecipitated with 74-5H7-bound immunoabsorbent. For each preparation, the purified proteins were subjected to SDS-PAGE under reducing conditions to monitor the purity and yield of the L1 glycoprotein. Figure $1 B$ shows that the $\mathrm{L} 1$ preparation contains equivalent amount of two polypeptides of approximately 180 and $140 \mathrm{kDa}$.

Enzymatic treatment of the NG2 proteoglycan. The NG2 proteoglycan was digested with protease-free chondroitinase $A B C$ in $40 \mathrm{~mm}$ Tris, $\mathrm{pH}$
$8.0,40 \mathrm{~mm}$ sodium acetate, $0.1 \mathrm{mg} / \mathrm{ml}$ BSA. Typically, $4 \mu \mathrm{g}$ of pure $\mathrm{NG} 2$ was incubated with $0.02 \mathrm{U}$ of chondroitinase $\mathrm{ABC}$ at $37^{\circ} \mathrm{C}$ for 1 $\mathrm{hr}$. The reaction mixture was cooled on ice and $1 \mathrm{~mm} \mathrm{CaCl}$, was added to inactivate the enzyme. In control experiments, NG2 was incubated with keratanase $(0.1 \mathrm{U} / \mu \mathrm{g} \mathrm{NG})$ in PBS (pH 7.4) containing $0.1 \mathrm{mg} / \mathrm{ml}$ $\mathrm{BSA}$ and protease inhibitors ( $2 \mathrm{mM}$ PMSF and $0.1 \mathrm{mg} / \mathrm{ml}$ leupeptin) at $37^{\circ} \mathrm{C}$ for $1 \mathrm{hr}$. For every digestion, an aliquot of reaction mixture was run on a $6 \%$ polyacrylamide gel to monitor the completeness of digestion.

Substrate preparation. Forty-eight well tissue culture plates were coated with $25 \mu \mathrm{g} / \mathrm{ml}$ of PLL overnight followed by $125 \mu 1$ of either L1 or laminin, both at $2 \mu \mathrm{g} / \mathrm{ml}$, or a mixture of the same amount of $\mathrm{Ll}$ or laminin and $0.5-10 \mu \mathrm{g} / \mathrm{ml}$ of the NG2 proteoglycan for $3 \mathrm{hr}$ at $37^{\circ} \mathrm{C}$. In some experiments, the PLL wells were first coated with $L 1$ or laminin and then coated with NG2 $(10 \mu \mathrm{g} / \mathrm{ml})$. The protein-coated surfaces were washed with PBS before seeding the neurons. To determine the amount of protein that had bound to the PLL-coated surfaces, the PLL wells were coated with ${ }^{125}$ I-labeled protein mixed with unlabeled protein and the amount bound determined by gamma counting of the substrates and/or the washes. The $\mathrm{Ll}$ and laminin were labeled with ${ }^{125}$ I-iodine using chloramine $T$ as described (Klinman and Howard, 1980) and ${ }^{125}$ I-labeled NG2 was purified from iodinated B49 cells as described above. In the antibody-blocking experiments, the PLL wells were coated as described above and then, after washing, treated with sterile rabbit anti-NG2 or normal rabbit IgG (both at $2 \mathrm{mg} / \mathrm{ml}$ ) for $1 \mathrm{hr}$ before seeding the cells.

The growth-modulating properties of NG2 were also evaluated using nitrocellulose-coated dishes (Lagenaur and Lemmon, 1987). Petri dishes $(35 \mathrm{~mm})$ were coated with $250 \mu \mathrm{l}$ of nitrocellulose dissolved in methanol ( $5 \mathrm{~cm}^{2}$ nitrocellulose in $12 \mathrm{ml}$ of methanol) and air dried in a tissue culture hood. One microliter droplets of different protein solutions (laminin, $\mathrm{L} 1$, intact $\mathrm{NG} 2$ proteoglycan, or the chondroitinase $\mathrm{ABC}$-digested NG2) were spotted onto nitrocellulose surface for $10 \mathrm{~min}$. After aspiration, the entire dish was washed with medium containing $10 \%$ fetal bovine serum and blocked in the same medium for $2 \mathrm{hr}$ at $37^{\circ} \mathrm{C}$. To create a boundary between NG2 and laminin or L1, we first spotted a small drop $(1 \mu \mathrm{l})$ of NG2 $(40 \mu \mathrm{g} / \mathrm{ml})$ onto nitroccllulosc, aspiratcd the drop off after $10 \mathrm{~min}$ and then spotted a larger droplet $(5 \mu \mathrm{l})$ of laminin $(10 \mu \mathrm{g} / \mathrm{ml})$ or $\mathrm{L} 1(40 \mu \mathrm{g} / \mathrm{ml})$ over the NG2 spot so that a circular border was formed with NG2 in the inner circle and laminin or L1 in the outer annulus. The dish was washed and blocked in medium with serum prior to adding the cells.

Cell cultures. B49 cells were grown in DMEM containing 10\% fetal bovine serum (FBS) and expanded every $3 \mathrm{~d}$.

Cerebellar granule neurons were purified from trypsin dissociates of postnatal day 5 or 6 rat cerebella on discontinuous Percoll gradients as described previously (Hatten, 1985). Neurons were seeded onto 48-well plates at 20,000 cells/well $\left(250 \mathrm{cells} / \mathrm{mm}^{2}\right)$ and onto nitrocellulose-coated dishes at $2 \times 10^{6}$ cells/dish in DMEM containing $10 \%$ FBS, $25 \mathrm{~mm}$ $\mathrm{KCl}$, and $20 \mathrm{ng} / \mathrm{ml} \mathrm{bFGF}$. After $24 \mathrm{hr}$, the cultures were washed in PBS and fixed in PBS containing $2 \%$ glutaraldehyde.

Dorsal root ganglia were isolated from embryonic day 15 rat fetuses and digested with $0.25 \%$ trypsin for $20 \mathrm{~min}$ at $37^{\circ} \mathrm{C}$. Following washing with serum-containing medium, the ganglia were mechanically dissociated by passage through flame-narrowed Pasteur pipettes. The cells were washed and preplated onto petri dishes in serum-containing medium for $2 \mathrm{hr}$ at $37^{\circ} \mathrm{C}$ to allow the non-neuronal cells to attach to the substrate. The DRG neurons were harvested, washed, and seeded at 3000 cells/well in DMEM containing 10\% FBS and $60 \mathrm{ng} / \mathrm{ml}$ nerve growth factor (a gift from Dr. S. Hálegoua). After $24 \mathrm{hr}$, the cultures were washed in PBS and fixed in $2 \%$ glutaraldehyde in PBS.

Immunostaining of protein-coated nitrocellulose substrate. Some cultures were immunofluorescently stained to visualize the protein spots on the nitrocellulose-coated surfaces. After 24 or $48 \mathrm{hr}$ growth, the cultures were washed in PBS and fixed in $3.7 \%$ formaldehyde in PBS. Following extensive PBS washes, the dishes were incubated with rabbit anti-NG2 $(1: 200)$ or rabbit anti-laminin antibodies (produced in the laboratory, 1:500) for $30 \mathrm{~min}$ at room temperature (RT). After 3 washes, the dishes were incubated with FITC labeled goat anti-rabbit IgG (Tago; 1:50) for $30 \mathrm{~min}$ at RT. The dishes were then washed in PBS and examined with a Leitz fluorescence microscope to reveal the substrate identities.

Quantitation of neurite length and cell attachment. Cultures were examined with an inverted phase contrast microscope and images were taken with a video camera (MTI 65) and stored in an imaging computer. 
Figure 1. Purification of the NG2 proteoglycan and the L1 glycoprotein. Protein samples were electrophoresed on $6 \%$ SDS-polyacrylamide gels and visualized by Coomassie blue staining. $A$, Purification of NG2. Lane 1, NP40 lysate of B49 cells. Lane 2, Immunoaffinity-purified NG2 $(2 \mu \mathrm{g})$. NG2 appears as a mixture of a high-molecularweight smear and a single polypeptide band of approximately $300 \mathrm{kDa}$. Lane 3 , NG2 digested with chondroitinase $\mathrm{ABC}\left(0.02 \mathrm{U}, 37^{\circ} \mathrm{C}, 1 \mathrm{hr}\right)$. Chondroitinase digestion causes the high-molecular-weight smear to disappear and increases the amount of $300 \mathrm{kDa}$ component. Lane 4, Chondroitinase $\mathrm{ABC}$ and digestion buffer alone. Arrows to the left indicate the mobility of molecular weight standards; from top to bottom, they are $200,000,116,000$, 97,400 , and $66,200 \mathrm{Da} . \mathrm{B}$, Purification of the L1 glycoprotein. Lane 1, Postnatal day 6 rat brain membranes extracted in deoxycholate as described in Materials and Methods. Lane 2, Immunoaffinity-purified L1 $(2 \mu \mathrm{g})$. L1 appears as two polypeptides of approximately 180 and $140 \mathrm{kDa}$. The mobility of the same molecular weight markers is indicated by the arrows to the left. The low-molecular-weight material in lane 2 of $A$ and $B$ is likely to be immunoglobulin light chain that leached off the immunoabsorbents.
A

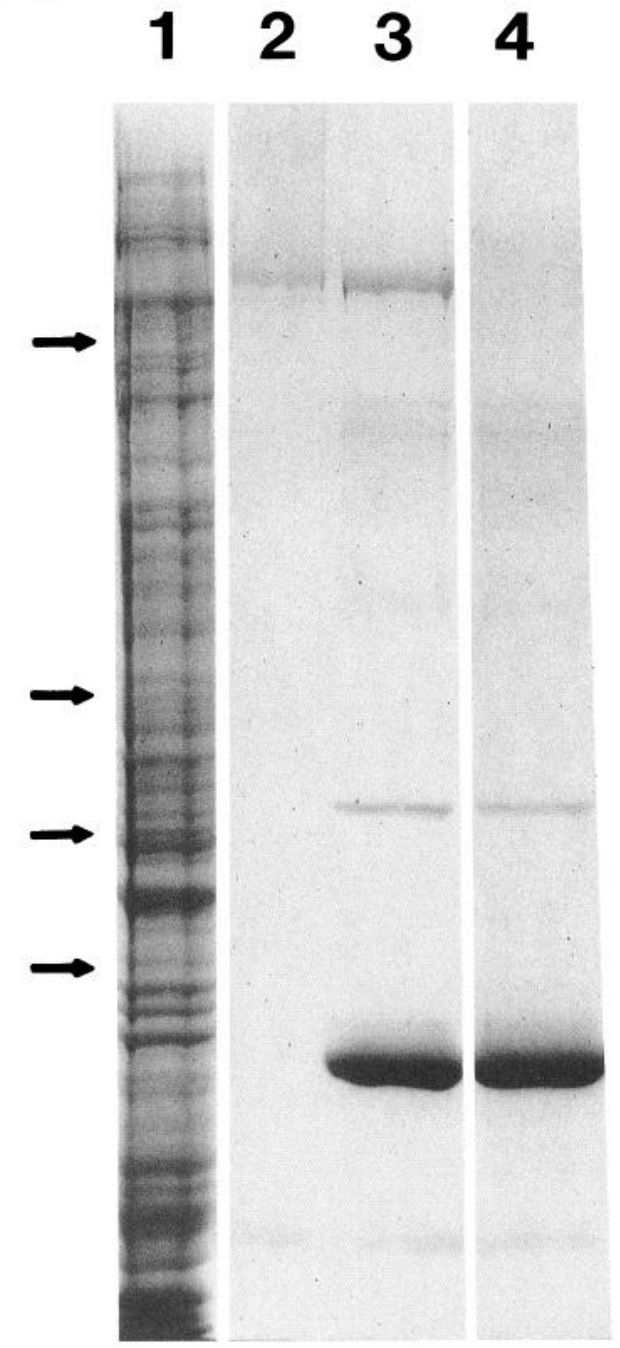

B

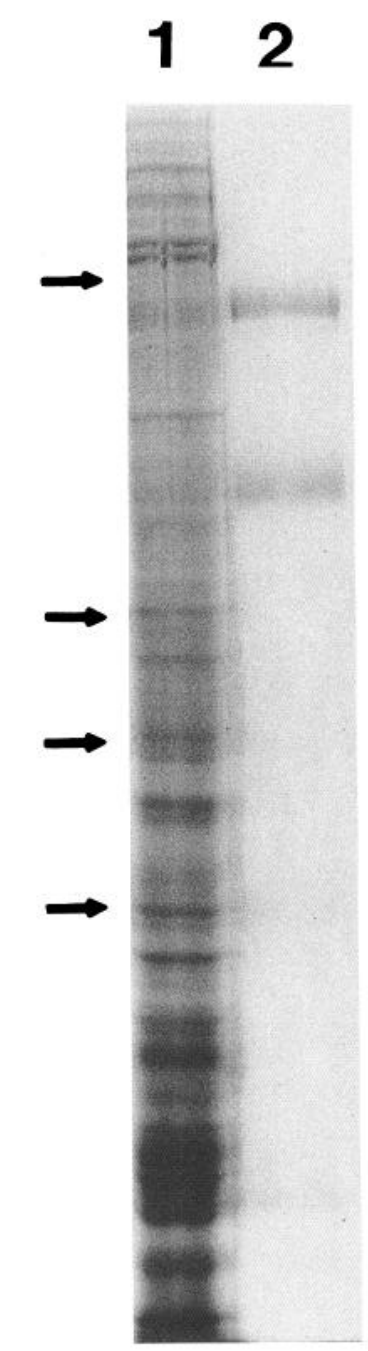

For each substrate condition, the number of cells attached and the number of cells with neurites per unit area were determined. The length of a minimum of 50 neurites from duplicate wells for each substrate condition were measured using software from Optimas and Infrascan Inc. Following the suggestion of Lagenaur and Lemmon (1987), a neurite was defined as a process extending from neuronal cell body by more than a cell diameter. Length was measured from the center of a cell body to the tip of the neurite. For cells that had more than one neurites, only the longest neurite was measured. A cumulative neurite length histogram was constructed for each experiment and data from separate experiments were pooled and analyzed. For the tables, percentage inhibition of neurite growth is defined as $\left[1-\left(\operatorname{mean}_{\text {expt }} / \operatorname{mean}_{\text {control }}\right)\right] \times$ 100 where mean $_{\text {expt }}$ is the mean length under the experimental conditions, and mean control is the mean of the appropriate controls.

\section{Results}

\section{NG2 does not support neuronal cell attachment and neurite} elongation

To examine the effects of NG2 on cell adhesion and neurite outgrowth, we adsorbed NG2 $(40 \mu \mathrm{g} / \mathrm{ml})$ onto nitrocellulosecoated surfaces (Lagenaur and Lemmon, 1987). Partially purified cerebellar granule neurons were seeded onto these substrates and cell attachment and neurite growth was assessed after 24 hr. As shown in Figure $2 A$, there is almost no cell attachment or neurite growth on the NG2-coated nitrocellulose. In control experiments, granule neurons were seeded onto nitrocellulose that had been coated with either laminin $(10 \mu \mathrm{g} / \mathrm{ml})$ or L1 $(40$ $\mu \mathrm{g} / \mathrm{ml}$ ). As shown in Figure $2 B$, laminin-coated nitrocellulose promoted extensive cell attachment and neurite outgrowth. Although cell attachment to L1-coated nitrocellulose was reduced relative to laminin, neurite outgrowth on the L1-coated nitrocellulose was robust (Fig. $2 C$ ). The cerebellar granule neurons did not attach to nitrocellulose alone (data not shown). Thus, the NG2 proteoglycan does not support neuronal cell attachment or neurite outgrowth.

\section{$N G 2$ inhibits neurite growth on laminin-coated surfaces}

To assay the effects of the NG2 proteoglycan on neurite elongation in the presence of the growth-promoting molecule laminin, we compared the growth of postnatal day 5 or 6 cerebellar granule neurons on surfaces coated with laminin to growth on surfaces coated with laminin and NG2. To determine the concentration of laminin that promotes optimal neurite growth from cerebellar granule neurons, the PLL-coated surfaces were coated with $0.5,2,10,25$, or $50 \mu \mathrm{g} / \mathrm{ml}$ of laminin and purified cerebellar granule neurons were seeded onto these substrates. 

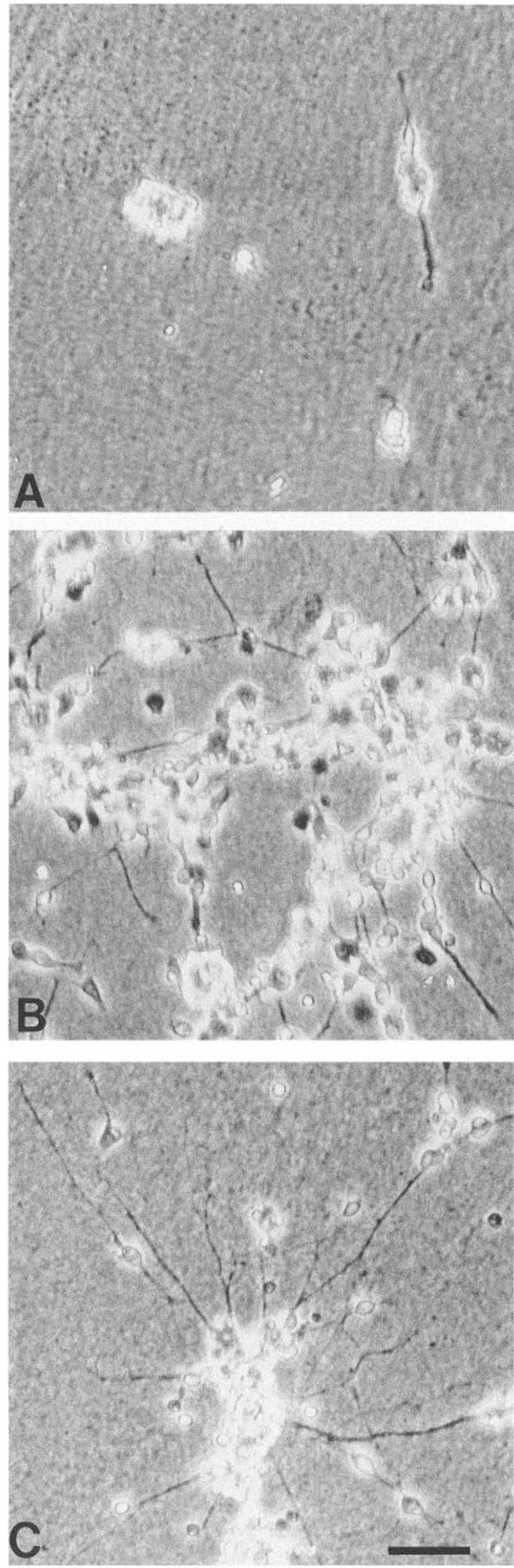

Figure 2. NG2 does not support cell adhesion and neurite outgrowth. Partially purified neonatal cerebellar granule neurons were seeded onto nitrocellulose-coated $35 \mathrm{~mm}$ dishes spotted with various proteins as described in Materials and Methods and were allowed to grow for 24 hr. $A$, Cells on the NG2 $(40 \mu \mathrm{g} / \mathrm{ml})$-coated nitrocellulose surface. $B$,
Neurite length was determined after $24 \mathrm{hr}$. On surfaces coated with $0.5 \mu \mathrm{g} / \mathrm{ml}$ of laminin, the mean neurite length was $60 \mu \mathrm{m}$. The mean neurite length increased with increasing laminin concentrations and reached a plateau at $10 \mu \mathrm{g} / \mathrm{ml}$ of laminin with a mean length of $95 \mu \mathrm{m}$. Surfaces coated with $2 \mu \mathrm{g} / \mathrm{ml}$ of laminin resulted in $90 \%$ of the maximal stimulation of neurite growth (mean length $=85 \mu \mathrm{m}$ ). Therefore, in the experiments described below, we used laminin at a concentration of $2 \mu \mathrm{g} / \mathrm{ml}$. We determined the amount of the input laminin that was bound to the substrate using ${ }^{125} \mathrm{I}$-laminin as described in Materials and Methods. At $2 \mu \mathrm{g} / \mathrm{ml}$, approximately $65 \%$ of the input laminin or $0.2 \mu \mathrm{g} / \mathrm{cm}^{2}$ of laminin bound to the PLL-coated surfaces. When surfaces were coated with the same concentration of laminin mixed with the NG2 proteoglycan at a concentration of 10 $\mu \mathrm{g} / \mathrm{ml}, 55 \%$ of the input laminin and $65 \%$ of the input NG2 bound to the PLL-coated surfaces. Thus, the amounts of laminin bound were sufficient to promote neurite outgrowth from cerebellar granule neurons under all conditions tested.

The cerebellar granule cells attached equally well to the laminin-coated surfaces and surfaces coated with a mixture of laminin and the NG2 proteoglycan (Table 1). However, whereas $52 \%$ of the attached cells extended neurites on laminin surfaces, only $27 \%$ of the cells did so on surfaces composed of laminin and the NG2 proteoglycan (Table 1). On the laminin and NG2 surfaces, the neurites were significantly shorter than on laminin alone. The results from 12 independent experiments are summarized in Figure $3 A$. Fifty percent of all neurites measured were greater than $80 \mu \mathrm{m}$ on the laminin substrates whereas on surfaces coated with laminin plus NG2 only $12 \%$ were longer than $80 \mu \mathrm{m}$. Despite this difference in neurite length, there were no obvious morphological differences between the cells grown on laminin alone and those grown on laminin mixed with the NG2 proteoglycan (compare Fig. $4 A, B$ ). When surfaces were coated first with laminin and then with NG2 rather than coated with a mixture of these two molecules, both the percentage of cells that extended neurites (34\%) and the mean neurite length $(54 \mu \mathrm{m})$ were decreased compared to cells growing on laminin alone (Table 1, Fig. $3 A$ ). This control experiment demonstrates that the NG2 proteoglycan need not interact with laminin in solution in order to neutralize the growth-promoting effects of laminin.

To demonstrate that the growth inhibitory effects observed are due to the NG2 proteoglycan, we treated the NG2/laminincoated surfaces with rabbit anti-NG2 antibodies and compared the growth of granule neurons on these substrates with growth on control surfaces that had been coated with laminin and treated with the same antibodies. As shown in Table 1, the mean neurite length on antibody-treated NG2/laminin surfaces (69 $\mu \mathrm{m})$ was not statistically different from the mean neurite length on the antibody-treated laminin control surfaces $(72 \mu \mathrm{m})$. When nonimmune rabbit IgG was used in place of the anti-NG2 IgG, neurite growth was inhibited to approximately the same extent as in cultures grown without any antibodies present (Table 1). These results indicate that the rabbit anti-NG2 antibodies can

Cells on laminin $(10 \mu \mathrm{g} / \mathrm{ml})$-coated substrate. $C$, Cells on $\mathrm{L} 1(40 \mu \mathrm{g}$ $\mathrm{ml}$ )-coated surfaces. Whereas cell attachment and neurite growth was extensive on laminin-coated nitrocellulose, there is almost no adhesion on the NG2-coated surfaces. Neurite outgrowth was robust on L1-coated surfaces although cell attachment was reduced relative to laminin-coated nitrocellulose. Scale bar, $50 \mu \mathrm{m}$. 


\section{A}
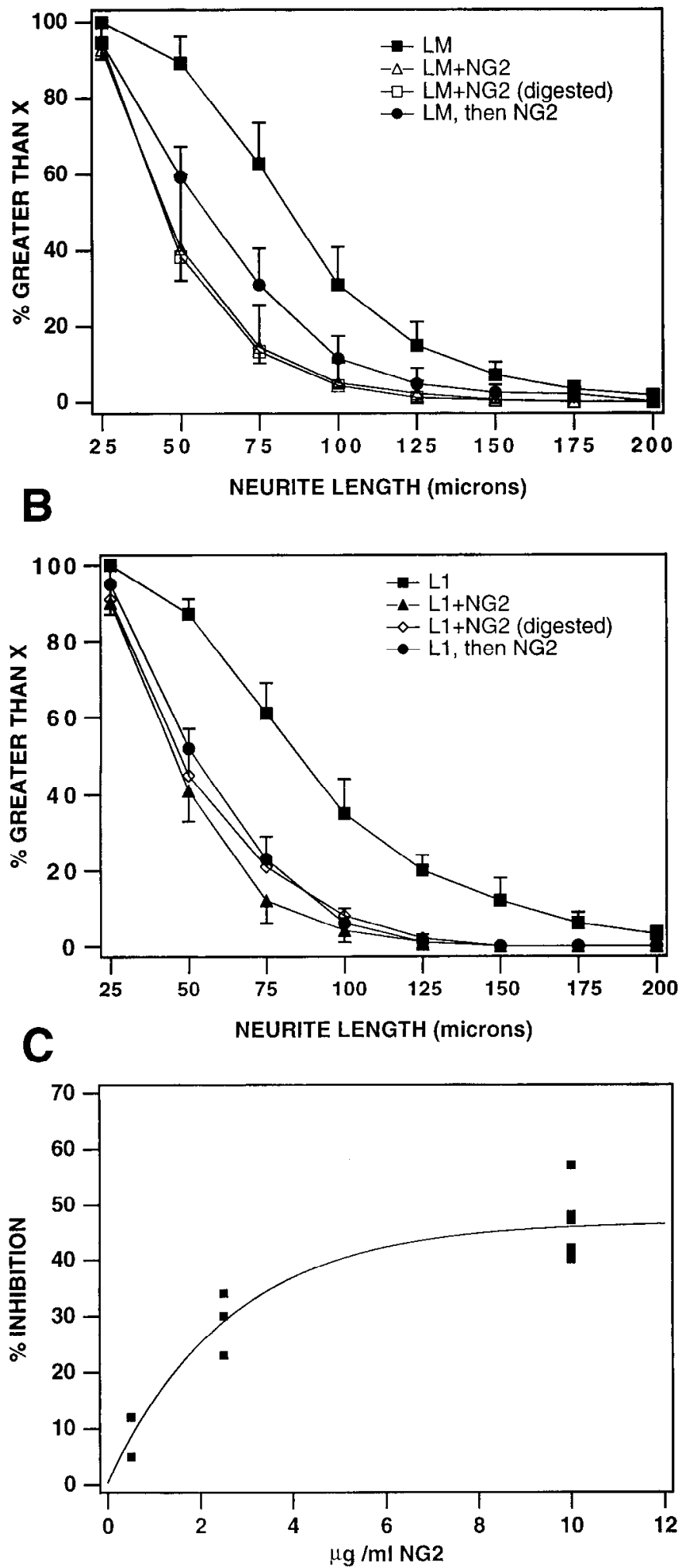

Figure 3. Quantitative analysis of neurite growth. A, A cumulative neurite length histogram showing the distribution of neurite lengths of cerebellar neurons grown on laminin alone, laminin mixed with NG2, laminin mixed with NG2 that had been digested with chondroitinase $\mathrm{ABC}$, and laminin followed by NG2. Data were pooled from 12 separate experiments and distribution was plotted as percentage of neurons with neurites $(y$-axis) longer than a given length $(x$-axis). $B$, Distribution of neurite lengths of cells grown on L1, L1 mixed with NG2, L1 mixed abolish the inhibitory activity of the NG2 proteoglycan and provide evidence that the NG2 proteoglycan is responsible for the inhibition of neurite outgrowth on laminin-coated surfaces.

\section{NG2 inhibits neurite extension on L1 substrates}

The data presented above demonstrate that the NG2 proteoglycan can inhibit the potent growth-promoting effects of laminin. However, little laminin has been detected in the developing CNS (Rogers et al., 1986; Letourneau et al., 1988). Rather, many CNS neurons extend their axons in areas rich in the L1 glycoprotein (Faissner et al., 1984; Stallcup et al., 1985). Therefore, we evaluated the ability of the NG2 proteoglycan to influence axonal elongation on Ll-coated surfaces.

We quantitatively analyzed the neurite growth from cerebellar granule neurons on surfaces coated with $0.5,1,2,10$, or $25 \mu \mathrm{g}$ / $\mathrm{ml}$ of immunoaffinity-purified L1. In agreement with previous studies using chick and mouse L1 (Lagenaur and Lemmon, 1987; Lemmon et al., 1989), the Ll glycoprotein isolated from rat brain membranes (see Fig. $1 B$ ) promoted extensive neurite outgrowth. Maximal neurite growth was obtained with $2 \mu \mathrm{g} / \mathrm{ml}$ of L1 (mean $=95 \mu \mathrm{m})$. At this concentration approximately $80 \%$ of the input Ll bound to the substrate. Higher concentrations of $\mathrm{L} 1$ resulted in a slight inhibition of neurite growth (data not shown). This inhibition may be due to contaminating polypeptides in the Ll preparation or to the small amounts of anti$\mathrm{L} 1$ antibody that may leach off the immunoaffinity resins. Accordingly, we carried out all the following experiments using L1 at $2 \mu \mathrm{g} / \mathrm{ml}$.

As was the case with laminin-coated surfaces, the granule neurons attached equally well to the $\mathrm{L} 1$ or the $\mathrm{NG} 2 / \mathrm{Ll}$-coated substrates (Table 1, Fig. $4 D, E$ ). On the L1-coated surfaces, $47 \%$ of the cells established neurites whereas on surfaces coated with I. 1 and the NG2 proteoglycan, only $20 \%$ of the attached cells extended neurites. As shown in Figure $3 B$ and Table 1, neurite growth on the L1/NG2-coated surfaces was reduced significantly relative to the growth on surfaces coated with $\mathrm{L} 1$ alone. The inhibition of neurite growth by NG2 occurred in a dose-dependent manner (Fig. $3 C$ ). Little or no inhibition was seen when the NG2 was used at $0.5 \mu \mathrm{g} / \mathrm{ml}$. The percentage of inhibition increased with increasing concentration of $\mathrm{NG} 2$, reaching a maximum of $45-50 \%$ inhibition when $10 \mu \mathrm{g} / \mathrm{ml}$ of $\mathrm{NG} 2$ was mixed with $2 \mu \mathrm{g} / \mathrm{ml}$ of $\mathrm{L} 1$. To determine whether NG2 needs to interact with $\mathrm{Ll}$ in solution in order to inhibit neurite growth, we employed the sequential coating procedure described above. As shown in Table 1 and Figure $3 B$, this sequential coating procedure resulted in the same degree of inhibition of neurite extension as did coating surfaces with a mixturc of L1 and NG2. Treatment with rabbit anti-NG2 antibodies abolished the inhibitory effects of the L1/NG2-coated substrates (Table 1). Taken together, these experiments demonstrate that the NG2 proteoglycan is a potent inhibitor of neurite outgrowth from cerebellar granule neurons on L1-coated surfaces, a molecule which is abundant within the developing cerebellar molecular layer (Faissner et al., 1984; Stallcup et al., 1985).

with NG2 that had been digested with chondroitinase $\mathrm{ABC}$, and $\mathrm{LI}$ followed by NG2. The error bars in $A$ and $B$ are SDs. Laminin and L1 were used at $2 \mu \mathrm{g} / \mathrm{ml}$ and NG2 used at $10 \mu \mathrm{g} / \mathrm{ml}$ in both $A$ and $B$. $C$, Dose-response curve of the NG2 proteoglycan in the presence of $\mathrm{L} 1$. Percentage of inhibition by NG2 on L1-coated surfaces (y-axis) was plotted against concentration of NG2 (x-axis). L1 was used at $2 \mu \mathrm{g} / \mathrm{m} 1$ throughout. 

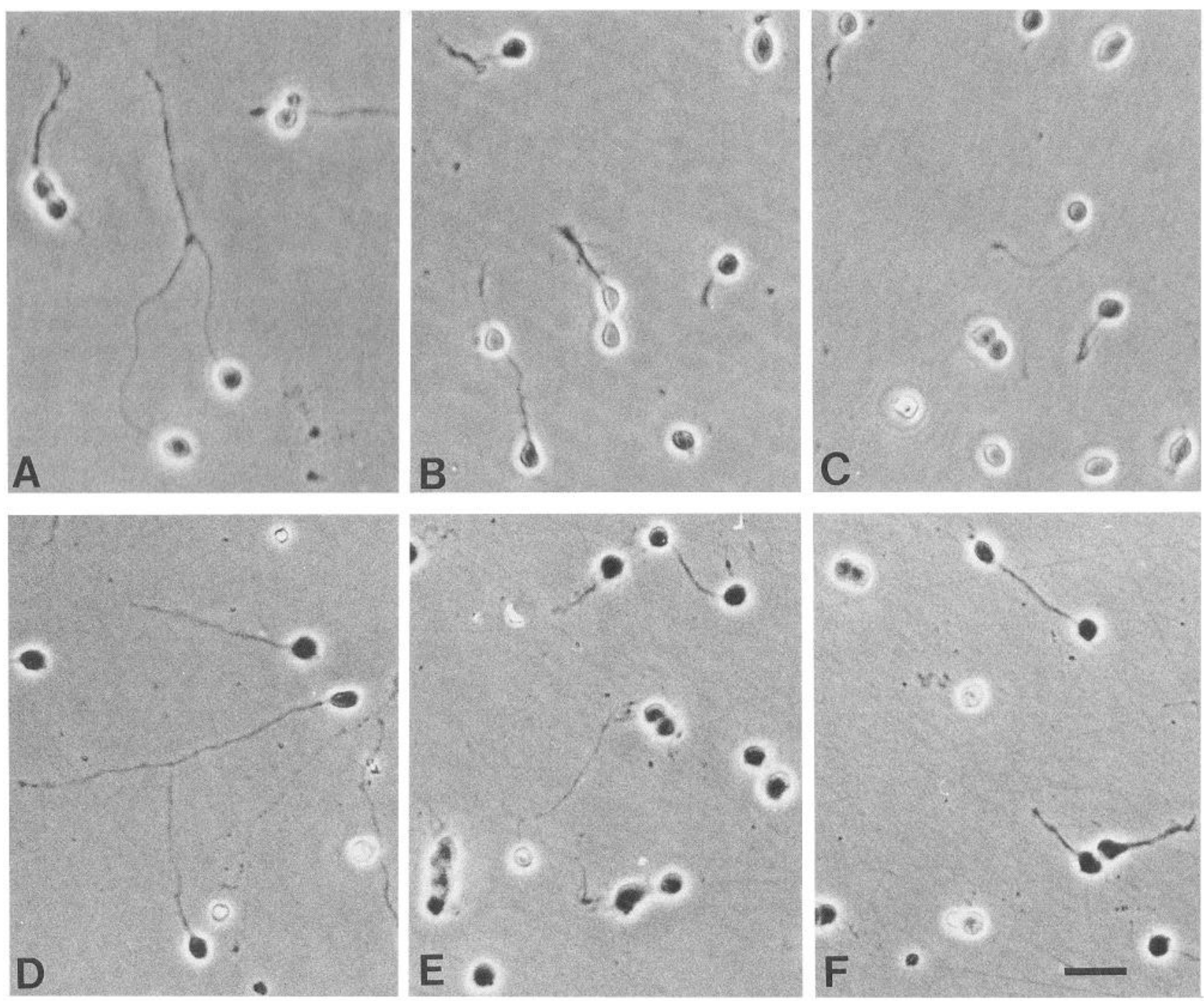

Figure 4. Appearance of neonatal cerebellar cells. Cells were plated onto PLL-coated tissue culture wells containing various substrates and grown for $24 \mathrm{hr}$ as described in Materials and Methods. The substrates are as follows: $A$, laminin; $B$, laminin mixed with the intact NG2 proteoglycan; $C$, laminin mixed with chondroitinase ABC-digested NG2; $D, \mathrm{~L} 1 ; E, \mathrm{~L} 1$ mixed with intact NG2; $F, \mathrm{~L} 1$ mixed with chondroitinase ABC-digested NG2. Laminin and L1 were used at $2 \mu \mathrm{g} / \mathrm{ml}$ and NG2 at $10 \mu \mathrm{g} / \mathrm{ml}$ throughout. Note that the neurites are significantly shorter on surfaces containing either intact or chondroitinase ABC-digested NG2 than on laminin or L1 alone. Scale bar, $25 \mu \mathrm{m}$.

\section{Inhibitory activity of the $N G 2$ core protein}

The GAG moieties of proteoglycans have been shown to exert both negative and positive influences over axonal growth in vitro (Snow et al., 1990; Cole and McCabe, 1991; Lafont et al., 1992). To determine whether the CS GAG chains are required for the growth inhibitory activity of the NG2 proteoglycan, we digested immunoaffinity-purified NG2 with either chondroitinase $A B C$ or keratanase and assayed the ability of the digestion products to modulate the growth of cerebellar granule neurons. Figure $1 \mathrm{~A}$ shows that digestion with chondroitinase $\mathrm{ABC}$ causes the high-molecular-weight smear component of NG2 to disappear and increases the relative amount of the $300 \mathrm{kDa}$ component. As described previously (Stallcup et al., 1983; Nishiyama et al., 1991), the high-molecular-weight smear represents the intact proteoglycan and the $300 \mathrm{kDa}$ component is the glycosylated core protein. Digestion of NG2 with keratanase had no effect on the electrophoretic mobility of the high-molecular-weight smear (not shown), indicating a lack of keratan sulfate chains in the molecule.

When cerebellar granule neurons were plated onto surfaces coated with laminin mixed with chondroitinase ABC-digested NG2, cell attachment did not differ significantly from attachment to surfaces coated either with laminin alone or with laminin and undigested NG2 (Table 1). Neurite outgrowth was reduced by $46 \%$ in agreement with the studies described above using the intact NG2 proteoglycan (Fig. 3A, Table 1). As shown in Figure $4 C$, the morphology of cells grown on laminin mixed with the NG2 core protein was identical to that of cells grown on laminin mixed with the intact proteoglycan. Thus, the NG2 core protein is sufficient to inhibit neurite growth on laminincoated surfaces.

The experiments described above suggest that the CS chains of the NG2 proteoglycan are not required for its growth inhibitory activity when mixed with laminin. To determine whether growth inhibition in the presence of the $\mathrm{L} 1$ glycoprotein is also 
Table 1. Inhibition of neurite growth from cerebellar neurons by the NG2 proteoglycan

\begin{tabular}{|c|c|c|c|c|}
\hline Substrate & Cells $/ \mathrm{mm}^{2}$ & $\begin{array}{l}\text { Cell with } \\
\text { neurites } / \mathrm{mm}^{2}\end{array}$ & $\begin{array}{l}\text { Neurite } \\
\text { length }(\mu \mathrm{m})\end{array}$ & $\begin{array}{l}\% \\
\text { Inhi- } \\
\text { bition }\end{array}$ \\
\hline $\operatorname{Laminin}(2 \mu \mathrm{g} / \mathrm{ml})$ & $95 \pm 24$ & $49 \pm 15$ & $85 \pm 12$ & \\
\hline Laminin + NG2 $(10 \mu \mathrm{g} / \mathrm{ml})$ & $86 \pm 21$ & $23 \pm 10^{b}$ & $48 \pm 11^{b}$ & 44 \\
\hline Laminin + NG2 (C'ase digested) & $88 \pm 22$ & $26 \pm 11^{b}$ & $46 \pm 5^{b}$ & 46 \\
\hline Laminin then $\mathrm{NG}^{a}{ }^{a}$ & $81 \pm 22$ & $28 \pm 13^{b}$ & $54 \pm 7^{b}$ & 36 \\
\hline Laminin + RantiNG2 & $94 \pm 16$ & $45 \pm 13$ & $72^{c}$ & \\
\hline Laminin $+\mathrm{NG} 2+$ RantiNG2 & $103 \pm 29$ & $46 \pm 15$ & $69^{c}$ & 4 \\
\hline Laminin + NG2 + NRS & ND & ND & $49^{b . c}$ & 32 \\
\hline $\mathrm{Ll}(2 \mu \mathrm{g} / \mathrm{ml})$ & $102 \pm 21$ & $48 \pm 11$ & $95 \pm 6$ & \\
\hline $\mathrm{L} 1+\mathrm{NG} 2(10 \mu \mathrm{g} / \mathrm{ml})$ & $100 \pm 38$ & $20 \pm 9^{b}$ & $50 \pm 5^{b}$ & 47 \\
\hline L1 + NG2 (C'asc digested) & $107 \pm 42$ & $23 \pm 11^{b}$ & $54 \pm 7^{b}$ & 43 \\
\hline $\mathrm{L} 1$ then $\mathrm{NG} 2^{\circ}$ & $113 \pm 11$ & $23 \pm 4^{b}$ & $57^{b . c}$ & 40 \\
\hline $\mathrm{L} 1+$ RantiNG2 & $84 \pm 14$ & $33 \pm 6$ & $78 \pm 3$ & \\
\hline $\mathrm{L} 1+\mathrm{NG} 2+$ RantiNG2 & $80 \pm 9$ & $27 \pm 9$ & $74 \pm 2$ & 5 \\
\hline $\mathrm{L} 1+\mathrm{NG} 2+\mathrm{NRS}$ & ND & ND & $46^{b, c}$ & 41 \\
\hline
\end{tabular}

Substrates were prepared and neurite outgrowth determined as described in Materials and Methods. Laminin and L1 were used at $2 \mu \mathrm{g} / \mathrm{ml}$ and NG2 was used at $10 \mu \mathrm{g} / \mathrm{ml}$ throughout. RantiNG2, rabbit IgG directed against NG2 core protein; NRS, normal rabbit serum. Both were used at $2 \mathrm{mg} / \mathrm{ml}$. Data shown are the means \pm SD from 3-12 separate experiments for each condition. ND, not determined; "C'ase digested" indicates digestion with chondrotinase $\mathrm{ABC}$.

${ }^{a}$ Sequential coating as described in Materials and Methods.

${ }^{b} p<0.001$ (Student's $t$ test); where not indicated, the numbers are not statistically different from the appropriate controls.

${ }^{c}$ Mean from duplicate wells of a single experiment.

independent of the GAG chains, we tested the ability of both chondroitinase $\mathrm{ABC}$ - and keratanase-digested NG2 to alter neurite outgrowth on surfaces coated with PLL and L1. As shown in Figure $3 B$ and Table 1, the inhibitory activity of the chondroitinase $\mathrm{ABC}$-digested $\mathrm{NG} 2$ was quantitatively identical to that of the intact proteoglycan (also compare Fig. $4 E, F$ ). Digestion of NG2 with keratanase had no effect on the ability of the NG2 proteoglycan to inhibit neurite outgrowth on L1-coated surfaces (data not shown). To rule out any nonspecific effects of the GAG lyases on L1-coated surfaces, we treated L1-coated substrates with calcium inactivated chondroitinase $\mathrm{ABC}$ and then plated cerebellar granule neurons onto these surfaces. In those experiments, $41 \%$ of attached cells extended neurites that had a mean length of $90 \mu \mathrm{m}$, a number that is not statistically different from that on control, L1-coated surfaces. Since digestion of NG2 with chondroitinase ABC may leave short stubs of CS attached to the core protein, we also tested the ability of chondroitin disaccharide sulfates to inhibit neurite growth on laminin and L1. Neither substrate-bound chondroitin disaccharide 4-sulfate nor chondroitin disaccharide 6-sulfate at 10 $100 \mu \mathrm{g} / \mathrm{ml}$ inhibited the growth of cerebellar granule neurons (data not shown). Taken together, these experiments suggest that the ability of the NG2 proteoglycan to inhibit the growth of cerebellar granule neurons under a variety of substrate conditions is a specific property of the core protein and is not necessarily associated with the covalently attached GAG chains.

The findings described above that implicate the NG2 core protein and not the GAG chains as an inhibitor of neurite outgrowth are in conflict with previous studies which suggested that the GAG chains are required for growth inhibition by proteoglycans (Snow et al., 1990; Cole and McCabe, 1991). These discrepancies could be due to differences between either the type of substrates or the type of neurons used in our experiments and in previous studies. We therefore tested the effects of purified GAGs on neurite outgrowth from neonatal cerebellar gran- ule neurons. As shown in Table 2, chondroitin sulfate, over a wide range of concentrations, inhibited the growth of cerebellar granule neurons on laminin-coated surfaces. Digestion of CS GAG with chondroitinase $A B C$ completely reversed this inhibition of neurite outgrowth. However, CS GAG was much less effective as a growth inhibitor when tested on the L1-coated surfaces. For example, whereas CS GAG at $10 \mu \mathrm{g} / \mathrm{ml}$ caused a $32 \%$ reduction in the mean neurite length on laminin substrates, a 10-fold higher concentration of chondroitin sulfate did not have a significant effect on neurite outgrowth on the L1-coated surfaces (Table 2). When CS GAG was used at $1 \mathrm{mg} / \mathrm{ml}$, however, neurite growth on L1-coated surfaces was inhibited. These results are consistent with the notion that the CS GAG chains of the NG2 proteoglycan are not required for an inhibition of neurite growth on L1-coated surfaces. It appears that both the NG2 core protein and the CS GAGs can each independently inhibit neurite outgrowth on laminin-coated surfaces.

\section{Neurites avoid the NG2 substrate}

In vitro, elongating growth cones will avoid substrates composed of inhibitory or repellent molecules (Walter et al., 1987; Caroni and Schwab, 1988a; Fawcett et al., 1989; Pesheva et al., 1989, 1993; Faissner and Kruse, 1990; Fichard et al., 1991). To determine whether elongating axons avoid surfaces coated with the NG2 proteoglycan, we examined the patterns of neurite growth from cerebellar granule neurons at borders of NG2 and laminin or L1. These borders were created by spotting a larger aliquot of either laminin or L1 over a smaller NG2 spot on nitrocellulose as described in Materials and Methods. Figure 5, $A$ and $C$, demonstrates that, in a choice situation, cerebellar cells attach to the laminin- or L1-coated substrates and very few cells adhere to those areas where the NG2 proteoglycan was spotted. Neurites growing on these substrates extended over the laminin- or L1-containing anmular surrounds and did not grow over the border between the laminin- or L1-containing annulus 
Table 2. Chondroitin sulfate inhibits neurite growth on laminin but not on L1-coated surfaces

\begin{tabular}{|c|c|c|c|c|}
\hline Substrate & Cells $/ \mathrm{mm}^{2}$ & $\begin{array}{l}\text { Cells with } \\
\text { neurites } / \mathrm{mm}^{2}\end{array}$ & $\begin{array}{l}\text { Neurite } \\
\text { length }(\mu \mathrm{m})\end{array}$ & $\begin{array}{l}\% \\
\text { Inhi- } \\
\text { bition }\end{array}$ \\
\hline $\operatorname{Laminin}(2 \mu \mathrm{g} / \mathrm{ml})$ & $95 \pm 24$ & $49 \pm 15$ & $85 \pm 12$ & \\
\hline Laminin + CS $(10 \mu \mathrm{g} / \mathrm{ml})$ & $80 \pm 17$ & $27 \pm 9^{a}$ & $58 \pm 7^{a}$ & 32 \\
\hline Laminin + CS $(10 \mu \mathrm{g} / \mathrm{ml} \text {, digested })^{b}$ & $89 \pm 15$ & $43 \pm 12$ & 78 & 8 \\
\hline Laminin $+\operatorname{CS}(100 \mu \mathrm{g} / \mathrm{ml})$ & $88 \pm 19$ & $16 \pm 10^{a}$ & $49 \pm 5^{a}$ & 42 \\
\hline Laminin + CS $(1 \mathrm{mg} / \mathrm{ml})$ & $74 \pm 24$ & $9 \pm 6^{a}$ & $48 \pm 11^{a}$ & 44 \\
\hline $\mathrm{L} 1(2 \mu \mathrm{g} / \mathrm{ml})$ & $102 \pm 21$ & $48 \pm 11$ & $95 \pm 6$ & \\
\hline $\mathrm{L} 1+\mathrm{CS}(10 \mu \mathrm{g} / \mathrm{ml})$ & $98 \pm 9$ & $59 \pm 13$ & $94 \pm 9$ & 1 \\
\hline $\mathrm{L} 1+\mathrm{CS}(100 \mu \mathrm{g} / \mathrm{ml})$ & $92 \pm 14$ & $57 \pm 10$ & $97 \pm 11$ & 0 \\
\hline $\mathrm{L} 1+\mathrm{CS}(100 \mu \mathrm{g} / \mathrm{ml}, \text { digested })^{b}$ & $102 \pm 14$ & $37 \pm 5$ & 97 & 0 \\
\hline $\mathrm{L} 1+\mathrm{CS}(1 \mathrm{mg} / \mathrm{ml})^{b}$ & $92 \pm 17$ & $16 \pm 4^{a}$ & $47^{a}$ & 50 \\
\hline
\end{tabular}

Cerebellar granule neurons were purified as described in Materials and Methods and plated into 48-well plates containing the indicated substrates. After $24 \mathrm{hr}$, cell attachment and neurite length were measured as described in Materials and Methods. Data shown are the mean and SD from at least three separate experiments. The data for growth on laminin and $\mathrm{L} 1$ alone are from Table 1. CS, chrondroitin sulfate (a mixture containing approximately $90 \%$ chondroitin 4-sulfate and $10 \%$ chondroitin 6-sulfate). "Digested" indicates treatment of chondroitin sulfate with chondroitinasc ABC.

${ }^{a} p<0.001$ (Student's $t$ test); where not indicated, values are not statistically different from the appropriate controls.

${ }^{b}$ Data from duplicate wells of a single experiment.

and the NG2-containing center. This avoidance of the NG2coated substrate was maintained for at least $48 \mathrm{hr}$ in culture at which time long neurites extended over those parts of the dish coated with the $\mathrm{L} 1$ glycoprotein (Fig. $5 D$ ). Immunofluorescence staining with rabbit anti-NG2 antibodies confirmed that the NG2 proteoglycan was present in the central area but not in the surrounding annulus (data not shown). NG2 that had been digested with chondroitinase or keratanase exhibited a similar inhibitory activity (data not shown). When nitrocellulose surfaces were spotted first with BSA at $40 \mu \mathrm{g} / \mathrm{ml}$ and then with laminin, no border effects were observed. Cells attached uniformly to the entire area and ncuritcs grew in both the central area and in the surrounding annulus (not shown). These results demonstrate that in a choice situation, cerebellar granule neurons and their processes avoid areas containing either the intact NG2 proteoglycan or its core protein.

\section{$N G 2$ effects on dorsal root ganglia neurons}

To determine whether the NG2 proteoglycan can inhibil the growth of other types of neurons, we tested the ability of the
NG2 proteoglycan to modulate neurite elongation from embryonic DRG neurons. As shown in Figure $6 A$ and Table 3, extensive neurite growth occurred on surfaces coated with $2 \mu \mathrm{g} / \mathrm{ml}$ of laminin. However, on surfaces that had been coated with a mixture of laminin and the NG2 proteoglycan $(10 \mu \mathrm{g} / \mathrm{ml})$, neurite length was reduced significantly (Table 3 ). The morphology of DRG neurons growing on the NG2-containing surfaces differed from that on the control surfaces. On laminin, most of the DRG neurons extended one or two neurites with $0-3$ branches from their cell bodies. On surfaces coated with laminin and the NG2 proteoglycan, the neurons gave rise to short neurites with many filopodia extending from both the growth cones and neurite shafts (compare Fig. 6A,B). Surprisingly, the NG2 proteoglycan had no significant effects on the growth of DRG neurons on L1-coated surfaces. Neurons extended neurites equally well on surfaces coated either with L1 alone or with L1 and NG2 (Table 3) and the cells growing on both surfaces were morphologically indistinguishable (compare Fig. 6C,D). These results suggest that the NG2 proteoglycan specifically inhibits the growth of cerebellar neurons but not DRG neurons on the

\begin{tabular}{|c|c|c|c|c|}
\hline & Neurons $/ \mathrm{mm}^{2}$ & $\begin{array}{l}\text { Cells with } \\
\text { neurites } / \mathrm{mm}^{2}\end{array}$ & $\begin{array}{l}\text { Neurite length } \\
(\mu \mathrm{m})\end{array}$ & $\begin{array}{l}\% \\
\text { Inhi- } \\
\text { bition }\end{array}$ \\
\hline Laminin $(2 \mu \mathrm{g} / \mathrm{ml})$ & $10.2 \pm 2.1$ & $7.5 \pm 1.7$ & $189 \pm 32$ & \\
\hline Laminin + NG2 $(10 \mu \mathrm{g} / \mathrm{ml})$ & $8.2 \pm 2.3$ & $3.5 \pm 0.7^{a}$ & $87 \pm 2^{a}$ & 54 \\
\hline Laminin + NG2 (C'ase digested) & $12.2 \pm 2.8$ & $4.3 \pm 0.9^{a}$ & $78^{a, b}$ & 59 \\
\hline $\mathrm{L} 1(2 \mu \mathrm{g} / \mathrm{ml})$ & $8.9 \pm 1.8$ & $5.8 \pm 0.9$ & $110 \pm 9$ & \\
\hline $\mathrm{L} 1+\mathrm{NG} 2(10 \mu \mathrm{g} / \mathrm{ml})$ & $9.1 \pm 1.5$ & $5.4 \pm 0.9$ & $119 \pm 15$ & 0 \\
\hline
\end{tabular}

Dorsal root ganglia neurons were removed from ED15 rat embryos and seeded into 48 -well plates at a density of 3000 neurons per well as described in Materials and Methods. After $24 \mathrm{hr}$, cell attachment and neurite length were measured. Data shown are the mean and SD from at least three separate experiments. "C'ase digested" indicates treatment with chondroitinase $\mathrm{ABC}$.

${ }^{a} p<0.001$ (Student's $t$ test); the mean neurite length on L1 + NG2 is not statistically different from that on L1 alone.

${ }^{b}$ Mean length from duplicate wells of a single experiment. 

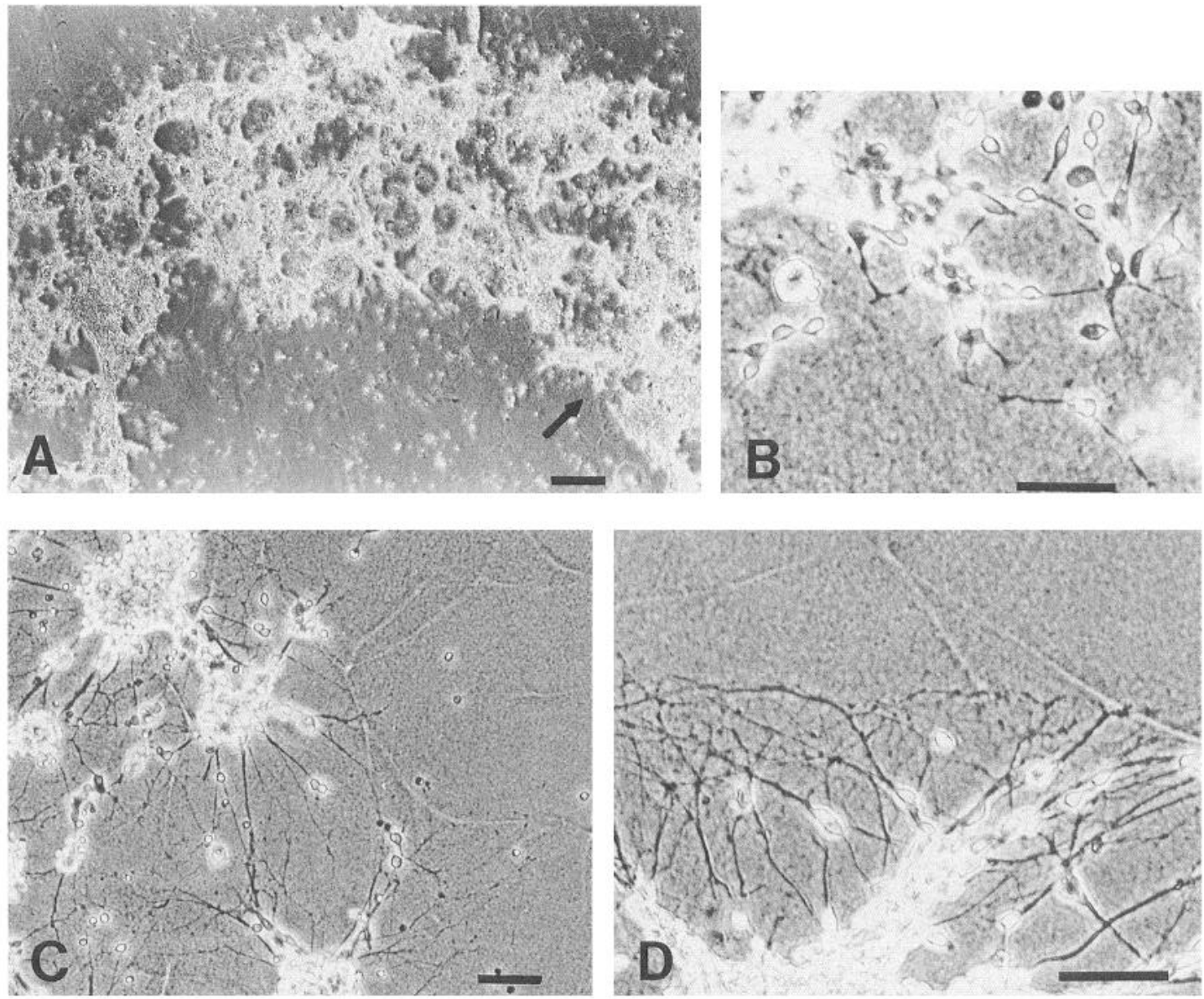

Figure 5. Neurites avoid NG2-containing substrates in a choice situation. Neonatal cerebellar granule neurons were seeded onto nitrocellulosecoated dishes containing NG2 in the center (3-mm-diameter circle) and laminin or L1 in a surrounding annulus as described in Materials and Methods. The cultures were photographed after 24 and $48 \mathrm{hr}$ growth. $A$, A low-magnification photograph showing the top half of such an annular arrangement $24 \mathrm{hr}$ after plating the cells. Few cells adhered to the NG2-containing central area and cells attached extensively to the laminincontaining annulus. $B$, An enlargement of the area indicated by the arrow in $A$. Note that neurites do not grow into the NG2-containing central area. $C$, A small section of an annular arrangement containing L1 to the left and NG2 in the center (shown on the right). This culture was photographed after $24 \mathrm{hr}$ growth, at which time neurites extended on the L1-containing surround but not on the NG2-containing center. $D$, After $48 \mathrm{hr}$ growth, neurites ramify extensively on the L1-containing surround (bottom half of $D$ ) and do not cross into the NG2-containing central area (shown to the top). Scale bars: $A, 250 \mu \mathrm{m} ; B-D, 50 \mu \mathrm{m}$.

L1-coated surfaces. On the other hand, the NG2 proteoglycan can inhibit the growth of both cerebellar and sensory neurons on laminin-coated surfaces.

\section{Discussion}

The proteoglycans of the nervous system comprise a highly diverse group of multifunctional macromolecules (Herndon and Lander, 1990). Although the chondroitin sulfate and keratan sulfate proteoglycans have attracted much attention recently as possible endogenous inhibitors of axonal growth (Snow et al., 1990; Cole and McCabe, 1991), the observations that proteoglycans can have both positive and negative effects on neurite growth (Iijima et al., 1991; Oohira et al., 1991) suggest that the biological properties of proteoglycans and their covalently attached GAG chains are complex. Here we have shown that NG2, a membrane-bound proteoglycan associated with the surfaces of $\mathrm{O} 2 \mathrm{~A}^{\text {nconatal }}$ and $\mathrm{O} 2 \mathrm{~A}^{\text {adult }}$ progenitor cells (Levine et al., 1993), inhibits the growth of neonatal cerebellar granule neurons on substrates composed of either laminin or L1. When granule neurons were given a choice between NG2-coated surfaces and laminin- or L1-coated surfaces, the neurites extended prefer- entially on laminin/L1 and appeared to avoid areas of the substrate containing NG2. The growth inhibitory activity was associated with the NG2 core protein and not the covalently attached CS GAG chains. The growth of DRG neurons was also inhibited by the NG2 proteoglycan; however, in this case, axonal growth was inhibited in the presence of laminin but not in the presence of the L1 glycoprotein. Thus, the developing glial precursor cells that express the NG2 proteoglycan in vivo are capable of defining areas of the developing CNS that are nonpermissive for axonal growth from selective populations of neurons.

The NG2 proteoglycan is a membrane spanning CSPG that was first identified with antibodies raised against the B49 cell line, a rat cell line with properties of both neurons and glial cells (Schubert et al., 1974; Wilson et al., 1981). There is no evidence for either dermatan sulfate (Stallcup et al., 1990) or keratan sulfate chains (Stallcup et al., 1983) in the NG2 proteoglycan. The primary sequence of the NG2 core protein suggests that it is a unique molecule and is not related to other families of either membrane spanning or extracellular proteoglycans (Nishiyama et al., 1991). Little is known about the functional properties of the NG2 proteoglycan. In previous studies, NG2 has been shown 

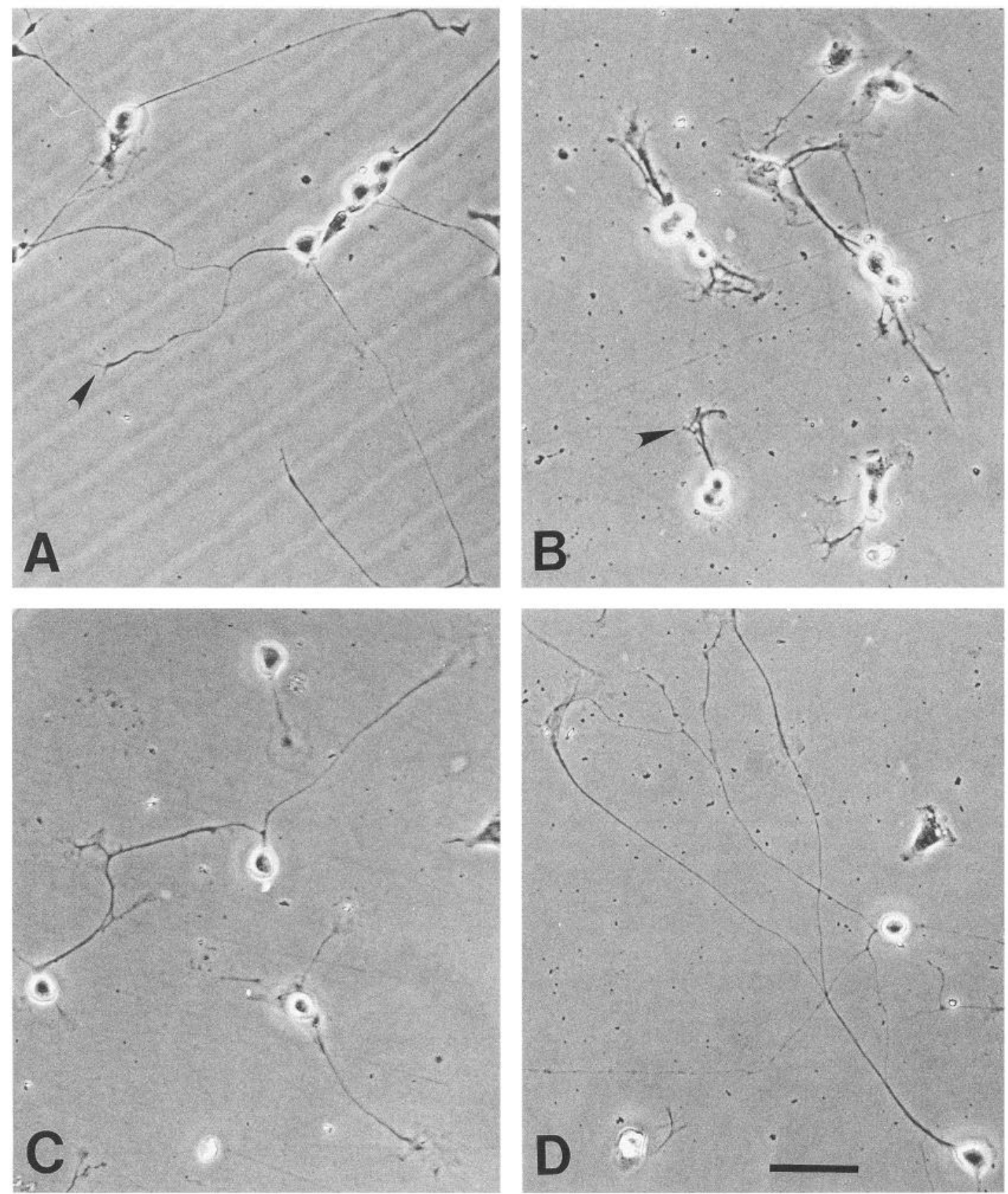

Figure 6. NG2 inhibits the growth of DRG neurons on laminin but not on L1-coated surfaces. Embryonic rat DRG neurons were seeded onto various substrates and allowed to grow for $24 \mathrm{hr}$ as described in Materials and Methods. $A$, Laminin substrate. Most neurons extended one or two long neurites. Notice the small growth cones with long filopodia (arrowhead). B, Laminin mixed with NG2. The neurites are significantly shorter than those on laminin alone. Numerous filopodia extend from flattened growth cones (arrowhead). $C$, L1. The DRG neurons extended one or two neurites with large growth cones characterized by lamellipodia. $D, \mathrm{~L} 1$ mixed with NG2. The neurons extended long neurites that were indistinguishable from cells grown on L1 alone. Laminin and $\mathrm{L} 1$ were used at $2 \mu \mathrm{g} / \mathrm{ml}$ and NG2 used at $10 \mu \mathrm{g} / \mathrm{ml}$ throughout. Scale bar, $50 \mu \mathrm{m}$.

to associate with type VI collagen, although the significance of this association for developing neurons and glial cells is unclear since type VI collagen has not been detected in brain (Stallcup et al., 1990).

The data presented here demonstrate that NG2 can inhibit neurite growth in vitro. Because surfaces coated with NG2 alone are nonadhesive for dissociated cerebellar cells, we used an experimental design in which the effects of NG2 on neurite extension were studied independent from any possible effects on cell adhesion. Under these conditions, the inhibition of axon growth from cerebellar neurons on L1-coated surfaces was con- centration-dependent with half maximal inhibition occurring when $3-5 \mu \mathrm{g} / \mathrm{ml}$ of NG2 was mixed with $2 \mu \mathrm{g} / \mathrm{ml}$ of L1. Thus, NG2 is active at concentrations (5-8 nM) comparable to those used in other studies of the growth inhibitory properties of brain proteoglycans (Cole and McCabe, 1991; Oohira et al., 1991) and between 200 and 300 times lower than that used in studies of a cartilage proteoglycan (Snow et al., 1990). The NG2 proteoglycan was an effective inhibitor of neurite growth on laminin at the same low concentrations.

The growth inhibition described here is dependent upon NG2 core protein and not the covalently attached CS GAG chains. 
Digestion of the NG2 proteoglycan with either chondroitinase $\mathrm{ABC}$ or keratanase did not alter the ability of this molecule to inhibit neurite growth. In the case of laminin, CS GAG chains and the NG 2 core protein each independently inhibited neurite growth. Laminin is a multifunctional molecule and contains an integrin-binding domain and several heparin-binding domains, all of which are capable of supporting cell attachment and neurite growth (Ignatius and Reichardt, 1988; Skubitz et al., 1988, 1991; Hall et al., 1990). Cerebellar neurons are thought to attach to and extend neurites on laminin via both integrin receptors and cell surface heparin sulfate proteoglycans (Werz and Schachner, 1988). The ability of some species of proteoglycans to interact with and modulate the functional properties of laminin is well established (Lander et al., 1985b; Riopelle and Dow, 1990). Therefore, blockage of any of the neurite-promoting domains in laminin by the NG2 core protein could result in a partial inhibition of ncuritc cxtension such as reported here. This blockage could result from either a direct molecular interaction between the $\mathrm{NG} 2$ core protein and the neurite-promoting domains on laminin or from NG2 binding elsewhere on laminin but sterically hindering granule neurons' access to the neuritepromoting domains.

In addition to inhibiting neurite growth on laminin, the NG2 core protein inhibited neurite growth on L1, a homophilic cellcell adhesion molecule that, unlike laminin, is abundant within the developing CNS (Faissner et al., 1984; Stallcup et al., 1985; Letourneau et al., 1988). The observation that CS and other GAGs are extremely weak inhibitors of neurite growth on L1 (Dou and Levine, 1993) suggests that the inhibition of growth on L1 surfaces may be the result of an interaction between L1 and the $\mathrm{NG} 2$ core protein. The $\mathrm{L} 1$ glycoprotein has been shown recently to have several extracellular domains that can independently promote neurite outgrowth from cercbcllar ncurons (Appel et al., 1993). As was the case with laminin, an interaction between the NG2 core protein and any of these neurite-promoting domains could disrupt the homophilic interactions between cell surface and substrate-bound $L 1$ and consequently inhibit neurite outgrowth. Interestingly, the core protein of neurocan, a soluble CSPG of the developing brain that is inhibitory to neuronal cell adhesion, also interacts with L1 (Grumet et al., 1993). The primary sequence of neurocan, however, shows no homologies with the primary sequence of NG2 (Nishiyama et al., 1991; Rauch et al., 1992).

The hypothesis that the NG2 proteoglycan can disrupt L1$\mathrm{L} 1$ interactions provides a simple molecular mechanism to explain our results with cerebellar neurons but fails to explain why NG2 is not an effective inhibitor of the growth of embryonic DRG neurons on L1-coated surfaces. Although substrate-bound L1 is a ligand for cell surface L1 (Lemmon et al., 1989), other CAMs such as axonin-1, TAG-1, and F3/11 can also serve as ligands for L1 (Kuhn et al., 1991; Pesheva et al., 1993; Felsenfeld et al., 1994). If embryonic rat DRG neurons used axonin-1 to interact with L1, as has been shown for chick sensory neurons, and if the domains of $\mathrm{L} 1$ to which axonin- 1 binds were different than the domains needed for L1-L1 interactions, this would explain the failure of the $\mathrm{NG} 2$ proteoglycan to inhibit axon extension from this particular neuronal type.

An alternate explanation for the growth inhibition reported here is that, rather than preventing cellular access to neuritepromoting domains of laminin and L1, substrate-bound NG2 interacts with neuronal cell surface molecules that act as receptors for NG2. The consequence of this putative receptor-ligand interaction may be a quenching of the actions of intracellular second messenger systems that are activated by cellular binding to laminin and L1 (Bixby, 1989; Schuch et al., 1989). Although the ability of our rabbit anti-NG2 antibodies to neutralize the growth inhibitory effects of NG2 would seem to favor such a ligand-receptor-second messenger model of NG2 action, these same antibodies could induce a conformational change in NG2 allowing neurons access to domains of laminin or L1 that mediate neurite growth. Experiments are currently under way to determine the mechanisms by which NG2 causes the growth inhibition reported here.

The finding that the NG2 core protein is functionally active as an inhibitor of neurite growth is consistent with previous studies demonstrating that the core proteins of rat brain CSPGs can inhibit neurite growth and cell attachment (Oohira et al., 1991; Grumet et al., 1993) but is in conflict with other studies demonstrating an inhibitory function for the GAG moieties of proteoglycans not the core proteins (Snow et al., 1990; Cole and McCabe, 1991). Differences in experimental design and reagents may explain this discrepancy. For example, Snow et al. (1990) used relatively high concentrations of a cartilage proteoglycan to inhibit the growth of embryonic chick DRG neurons. The CS and KS GAG chains make up a larger proportion (90\%) of the total mass of the cartilage proteoglycan than do the CS GAGs of NG2 (Hascall et al., 1991; Nishiyama et al., 1991) so that surfaces coated with the cartilage proteoglycan would contain a higher density of negative charges when compared to surfaces coated with NG2. These negative charges could discourage cell attachment and neurite extension.

The distribution of the NG2 proteoglycan during neuronal development has been studied extensively in the rat cerebellar cortex (Levine and Card, 1987; Levine et al., 1993). There, NG2-positive glial precursor cells are initially found within the internal granule layer and at the level of the Purkinje cell bodies. The superficial aspects of the developing molecular layer are relatively free of NG2-expressing cells. Thus, as the newly generated granule cells extend their axons through the molecular layer (Altman, 1972), they do so above a layer of NG2-positive cells (Bicknese and Levine, unpublished observations). Such a topographical arrangement is consistent with both the growth inhibitory properties of the NG2 proteoglycan and the observation that neurites appear to avoid substrates containing the NG2 proteoglycan. This suggests that NG2-positive glial cells may contribute to cerebellar morphogenesis by helping to keep growing parallel fibers stacked within the molecular layer (Altman, 1972). Expression of the NG2 proteoglycan is also transiently increased after acute brain injury in adult animals (Levine, 1994). Thus, in addition to playing a growth modulatory role during development, the NG2 protcoglycan may also contribute to the failure of damaged CNS neurons to regenerate successfully.

\section{References}

Altman J (1972) Postnatal development of the cerebellar cortex in the rat. I. The external germinal layer and the transitional molecular layer. J Comp Neurol 145:353-398.

Appel F, Holm J, Conscience J-F, Schachner M (1993) Several extracellular domains of the neural cell adhesion molecule $L 1$ are involved in neurite outgrowth and cell body adhesion. J Neurosci 13:4764 4775.

Bixby JL (1989) Protein kinase C is involved in laminin stimulation of neurite outgrowth. Neuron 3:287-297. 
Bradford MM (1976) $\Lambda$ rapid and sensitive method for the quantitation of microgram quantities of protein utilizing the principle of protein dye binding. Anal Biochem 72:248-254.

Caroni P, Schwab ME (1988a) Two membrane protein fractions from rat central myelin with inhibitory properties for neurite growth and fibroblast spreading. J Cell Biol 106:1281-1288.

Caroni P, Schwab ME (1988b) Antibody against myelin-associated inhibitor of neurite growth neutralizes nonpermissive substrate properties of CNS white matter. Neuron 1:85-96.

Cole GJ, McCabe CF (1991) Identification of a developmentally regulated keratan sulfate proteoglycan that inhibits cell adhesion and neurite outgrowth. Neuron 7:1007-1018.

Davies JA, Cook GMW, Stern CD, Keynes RJ (1990) Isolation from chick somites of a glycoprotein fraction that causes collapse of dorsal root ganglion growth cones. Neuron 4:11-20.

Dou CL, Levine JM (1993) Differential effects of glycosaminoglycans on neurite extension on L1 and laminin substrates. Soc Neurosci Abstr 19:1090.

Faissner A, Kruse $\mathbf{J}$ (1990) $\mathbf{J} 1 /$ tenascin is a repulsive substrate for central nervous system neurons. Neuron 5:627-637.

Faissner A, Kruse J, Nieke J, Schachner M (1984) Expression of neural cell adhesion molecule $\mathrm{L} 1$ during development in neurological mutants and in the peripheral nervous system. Dev Brain Res 15:69-82.

Fawcett JW, Rokos J, Bakst I (1989) Oligodendrocytes repel axons and cause axonal growth cone collapse. J Cell Sci 92:93-100.

Felsenfeld DP, Hynes MA, Skoler KM, Furley AJ, Jessel TM (1994) TAG-1 can mediate homophilic binding, but neurite outgrowth on TAG-1 requires an L1-like molecule and $\beta 1$ integrins. Neuron 12: 675-690.

Fichard A, Verna JM, Olivares J, Saxod R (1991) Involvement of chondroitin sulfate proteoglycan in the avoidance of chick epidermis by dorsal root ganglia fibers: a sludy using $\beta$-D-xyloside. Dev Biol 148:1-9.

Goodman CS, Shatz CJ (1993) Developmental mechanisms that generate precise patterns of neuronal connectivity. Neuron [Suppl] 10: $77-98$.

Grumet M, Flaccus A, Margolis RU (1993) Functional characterization of chondroitin sulfate proteoglycans of brain: interactions with neurons and neural cell adhesion molecules. J Cell Biol 120:81 5-824.

Hall DE, Reichardt LF, Crowley F, Holley B, Moezzi H, Sonnenberg A, Damsky CH (1990) The $\alpha 1 / \beta 1$ and $\alpha 6 / \beta 1$ integrin heterodimers mediate cell attachment to distinct sites on laminin. J Cell Biol 110: 2175-2184.

Hascall VC, Heinegard DK, Wight TN (1991) Proteoglycans: metabolism and pathology. In: Cell biology of extracellular matrix (Hay E, ed).

Hatten ME (1985) Neuronal regulation of astroglial morphology and proliferation in vitro. J Cell Biol 100:384-396.

Herndon ME, Lander AD (1990) A diverse set of developmentally regulated proteoglycans is expressed in the rat central nervous system. Neuron 4:949-961

Hubbard AL, Cohn ZA (1972) The enzymatic iodination of the red cell membrane. J Cell Biol 55:390-405.

Ignatius MJ, Reichardt LF (1988) Identification of a neuronal laminin receptor: a $M, 200 \mathrm{~K} / 120 \mathrm{~K}$ integrin heterodimer that binds laminin in a divalent cation-dependent manner. Neuron 1:713-725.

Iijima N, Oohira A, Mori T, Kitabatake K, Kohsaka S (1991) Core protein of chondroitin sulfate proteoglycan promotes neurite outgrowth from cultured neocortical neurons. J Neurochem 56:706-708.

Klinman DM, Howard JC (1980) Protein iodination suitable for labeling hybridoma antibodies. In: Monoclonal antibodies (Kennett RH, et al., eds), pp 401-402.

Kuhn TB, Stoeckli ET, Condrau MA, Rathjen FG, Sonderegger P (1991) Neurite outgrowth on immobilized axonin-1 is mediated by a heterophilic interaction with L1 (G4). J Cell Biol 115:1113-1126.

Lafont F, Rouget M, Triller A, Prochiantz A, Rousselet A (1992) In vitro control of neuronal polarity by glycosaminoglycans. Development 114:17-29.

Lagenaur C, Lemmon V (1987) An L1-like molecule, the 8D9 antigen, is a potent substrate for neurite extension. Proc Natl Acad Sci USA 84:7753-7757.

Lander AD, Fujii DK, Reichardt LF (1985a) Laminin is associated with the "neurite outgrowth-promoting factors" found in conditioned medium. Proc Natl Acad Sci USA 82:2183-2187.

Lander AD, Fujii SK, Reichardt LF (1985b) Purification of a factor that promotes neurite outgrowth: isolation of laminin and associated molecules. J Cell Biol 101:898-913.

Lemmon V, Farr KL, Lagenaur C (1989) L1-mediated axon outgrowth occurs via a homophilic binding mechanism. Neuron 2:1597-1603.

Lemmon V, Burden SM, Payne HR, Elmslie GJ, Hlavin ML (1992) Neurite outgrowth on different substrates: permissive versus instructive influences and the role of adhesive strength. J Neurosci 12:818826.

Letourneau PC, Madsen AM, Palm SL, Furcht LT (1988) Immunoreactivity for laminin in the developing ventral longitudinal pathway of the brain. Dev Biol 125:135-144.

Levine JM (1994) Increased expression of the NG2 chondroitin-sulfate proteoglycan after brain injury. J Neurosci, in press.

Levine JM, Card JP (1987) Light and electron microscopic localization of a cell surface antigen (NG2) in the rat cerebellum: association with smooth protoplasmic astrocytes. J Neurosci 7:2711-2720.

Levine JM, Stallcup WB (1987) Plasticity of developing cerebellar cells in vitro studied with antibodies against the NG2 antigen. J Neurosci 7:2721-2731.

Levine JM, Stincone F, Lee YS (1993) Development and differentiation of glial precursor cells in the rat cerebellum. Glia 7:307-321.

Luo Y, Raible D, Raper JA (1993) Collapsin: a protein in brain that induces the collapse and paralysis of neuronal growth cones. Cell 75 : 217-227.

MacSween JM, Eastwood SL (1978) Recovery of immunologically active antigen from staphylococcal protein A-antibody adsorbent. J Immunol Methods 23:259-267.

Maeda N, Matsui F, Oohira A (1992) A chondroitin sulfate proteoglycan that is developmentally regulated in the cerebellar mossy fiber system. Dev Biol 151:564-574.

Nishiyama A, Dahlin KJ, Prince JT, Johnstone SR, Stallcup WB (1991) The primary structure of NG2, a novel membrane-spanning proteoglycan. J Cell Biol 114:359-371.

Oohira A, Matsui F, Katoh-Semba R (1991) Inhibitory effects of brain chondroitin sulfate proteoglycans on neurite outgrowth from PC12D cells. J Neurosci 11:822-827.

Patterson PH (1988) On the importance of being inhibited, or saying no to growth cones. Neuron 1:263-267.

Pesheva P, Spiess E, Schachner M (1989) J1-160 and J1-180 are oligodendrocyte-secreted non-permissive substrates for cell adhesion. J Cell Biol 109:1765-1778.

Pesheva P, Gennarini G, Goridis C, Schachner M (1993) The F3/11 cell adhesion molecule mediates the repulsion of neurons by the extracellular matrix glycoprotein J1-160/180. Neuron 10:69-82.

Pettway Z, Guillory G, Bronner-Fraser M (1990) Absence of neural crest cells from the region surrounding implanted notochords in situ. Dev Biol 142:335-345.

Rauch U, Laina K, Maurel P, Margolis RU, Margolis RK (1992) Cloning and primary structure of neurocan, a developmentally regulated, aggregating chondroitin sulfate proteoglycan of brain. $\mathrm{J}$ Biol Chem 267:19536-19547.

Riopelle RJ, Dow KE (1990) Functional interactions of neuronal heparan sulphate proteoglycans with laminin. Brain Res 525:92-100.

Rogers SL, Edson KL, Letourneau PC, McLoon SC (1986) Distribution of laminin in the developing peripheral nervous system of the chick. Dev Biol 113:429-435.

Rutishauser U, Jessell TM (1988) Cell adhesion molecules in vertebrate neural development. Physiol Rev 68:819-857.

Sanes JR (1989) Extracellular matrix molecules that influence neural development. Annu Rev Neurosci 12:491-516.

Schubert D, Heinemann S, Carlisle W, Tarikas H, Kimes B, Patrick J, Steinbach J, Culp W, Brandt B (1974) Clonal cell lines from the rat central nervous system. Nature 249:224-227.

Schuch U, Lohse MJ, Schachner M (1989) Neural cell adhesion molecules influence second messenger systems. Neuron 3:13-20.

Skubitz APN, McCarthy JB, Charonis AS, Furcht LT (1988) Localization of three distinct heparin-binding domains of laminin by monoclonal antibodies. J Biol Chem 263:4861-4868.

Skubitz APN, Letourneau PC, Wayner E, Furcht LT (1991) Synthetic peptides from the carboxy-terminal globular domain of the A chain of laminin: their ability to promote cell adhesion and neurite outgrowth, and interact with heparin and the 1 integrin subunit. J Cell Biol 115:1137-1148.

Snow DM, Lemmon V, Carrino DA, Caplan AI, Silver J (1990) Sulfated proteoglycans in astroglial barriers inhibit neurite outgrowth in vitro. Exp Neurol 109:111-130. 
Stallcup WB, Beasley L, Levine JM (1983) Cell surface molecules that characterize different stages in the development of cerebellar interneurons. Cold Spring Harbor Symp Quant Biol 48:761-774.

Stallcup WB, Beasley L, Levine JM (1985) Antibody against nerve growth factor-inducible large external (NILE) glycoprotein labels nerve fiber tracts in the developing rat nervous system. J Neurosci 5:10901101 .

Stallcup WB, Dahlin K, Healy P (1990) Interaction of the NG2 chondroitin sulfate proteoglycan with type VI collagen. J Cell Biol 111: 3177-3188.

Walter J, Henke-Fahle S, Bonhoeffer F (1987) Avoidance of posterior tectal membranes by temporal retinal axons. Development 101:909_ 913.

Werz W, Schachner M (1988) Adhesion of neural cells to extracellular matrix constituents. Involvement of glycosaminoglycans and cell adhesion molecules. Dev Brain Res 43:225-234.

Wilson SS, Baetge EE, Stallcup WB (1981) Antisera specific for cell lines with mixed neuronal and glial properties. Dev Biol 83:146-153.

Zaremba S, Guimararaes A, Kalb RG, Hockfield S (1989) Characterization of an activity-dependent, neuronal surface proteoglycan identified with monoclonal antibody Cat-301. Neuron 2:1207-1219. 